\title{
Homelands and Nationalism
}

\author{
Nadav G. Shelef* (iD) and Alex Zhi-Xiong Koo \\ University of Wisconsin, Madison, USA \\ *Corresponding author. Email: shelef@wisc.edu
}

\begin{abstract}
Homelands are an integral component of nationalism. This recognition notwithstanding, the lines nationalism draws on the globe have received much less systematic attention than the lines drawn between in-groups and out-groups. This article argues that homelands, precisely because they are so central to nationalism, should be more consistently integrated into scholarship on international conflict, among other outcomes. We begin by detailing what homelands are, why they matter, and some suggested mechanisms for how they impact outcomes of interest. The next section considers the choices scholars make about identifying homelands, including the particular measurement strategy and the level of analysis used. Here, we highlight recent advances that enable the measurement and analysis of homelands in ways consistent with both constructivist insights about the possibility of variation in the homeland's extent (both over time and within populations) and with positivist analysis. We conclude by sketching out future directions for research on homelands and nationalism.
\end{abstract}

Keywords: nationalism; homelands; partition

Homelands are an integral component of nationalism. Indeed, scholars espousing quite different theoretical understandings of the origins of nations and nationalism all posit some version of Smith's recognition that nations "always possess ties to a particular locus of territories, which they call their 'own"” $(1987,29)$. The centrality of territory led Agnew to conclude that, "borders are kit and caboodle [...] to everyday nationalism" $(2007,403)$.

This recognition notwithstanding, the lines nationalism draws on the globe have received much less systematic attention than the lines drawn between in-groups and out-groups. This article argues that homelands, precisely because they are so central to nationalism, should be more consistently integrated into scholarship on international conflict, among other outcomes. We begin by detailing what homelands are, why they matter, and some suggested mechanisms for how they impact outcomes of interest. The next section considers the choices scholars make about identifying homelands, including the particular measurement strategy and the level of analysis used. Here, we highlight recent advances that enable the measurement and analysis of homelands in ways consistent with both constructivist insights about the possibility of variation in the homeland's extent (both over time and within populations) and with positivist analysis. We conclude by sketching out future directions for research on homelands and nationalism.

\section{What Are "Homelands"?}

Homelands are a nationalist form of territoriality. Territoriality is an attempt "to affect, influence, or control people, phenomena, and relationships, by delimiting and asserting control over a

(C) The Author(s), 2021. Published by Cambridge University Press. This is an Open Access article, distributed under the terms of the Creative Commons Attribution licence (http://creativecommons.org/licenses/by/4.0/), which permits unrestricted re-use, distribution, and reproduction in any medium, provided the original work is properly cited. 
geographic area" (Sack 1986, 19). The designation of some land as "the homeland" is a specific form of territoriality engendered by the idea that a particular group of people (the "nation") ought to control a specific territory because that land is part of who the people are (Penrose 2002; Shelef 2020a).

While abstract nations are not necessarily tied to a specific location, they do have to be located somewhere. This is the case because the desire for sovereignty that animates the national project (Anderson 1991, 6) requires a geographical location in which this sovereignty is to be exercised (Agnew 1994). In this vein, Hans Kohn argued that nationalism "presupposes the existence, in fact or as an ideal, of a centralized form of government over a distinct and large territory" $(1939,1002)$. This requirement is also why the common conceptualization of nationalism as the drive to make the cultural and political borders of the nation congruent (Gellner 1983; Hechter 2000) similarly assumes a territorial component to these borders.

This territorial imperative leads nationalists to identify a particular piece of land as their "home" land. The specific borders of the homeland may be based on the "cultural regions" (Conzen 1993) that encompass the locations groups are historically from, in which they reside, and to whose landscapes they may be emotionally tied. Such cultural regions may be especially likely to constitute the homeland where a single ethnic group serves as the basis for a nationalism.

Homelands, however, may also arise from, and their contours shaped by, processes that do not depend on having an ethnic precursor to the nation. For instance, the borders of the homeland may reflect the legacy of solutions to past coordination dilemmas (Abramson and Carter 2016; Carter and Goemans 2011; Goemans 2006). The homeland's extent may also be reshaped over time by the consequences of domestic political contestation and the legitimization strategies deployed by domestic political actors (Goddard 2010; Lustick 1993; Shelef 2010; Shelef 2020a).

Even where cultural regions serve as the basis for delimiting the homeland, nationalist "homelands" are qualitatively distinct from ethnic "home lands". Nationalism fundamentally transforms mere land, including cultural regions, into the territorialized embodiment of collective identity (Burghardt 1973; Gottmann 1973; Murphy 2002; Taylor 1994). In so doing, nationalism provides a story that "tie[s] together the fate of the nation and the territory[... and] explain[s] why a given territory belongs rightfully to the nation, how the nation arrived at the present territorial situation, and which territory would fulfil [the nation's] destiny" (Herb $2004,156)$. The constitutive role homelands play in nationalism explains why nationalists devote so much costly energy to maps, geography textbooks, and seemingly quixotic battles over the names used to label particular places.

Nationalism, in other words, combines the potentially apolitical attachment to land with the imperative to exert a group's control over that territory. This binding of nation and territory constrained the territorial horsetrading between polities that had been the norm prior to nationalism's emergence and transformed the loss of homeland territory into something worth dying for (Cederman 2013; Hall 1999; Kadercan 2017; Shelef 2016). This is the case, importantly, for all nations and all nationalisms. Even so-called civic or inclusive nationalisms-nationalisms that use the borders of the state rather than ethnic criteria to define their membership boundaries-are territorially grounded. They too seek exclusive sovereignty over a "homeland."

\section{Why Homelands Matter?}

This understanding of the ideational value of homelands has two main implications for current scholarship. First, it suggests that homelands ought to be included as a variable that could shape phenomena like international conflict, secession, irredentism, and partition, among others. Second, it suggests that operationalizing homelands solely in material terms likely underestimates their impact and omits potentially consequential variation.

Studies of conflict, both civil and international, commonly note the economic, strategic, and demographic value of territory (e.g., Buhaug, Cederman, and Rød 2008; Carter 2010; Fearon and 
Laitin 2003; Gibler 2012; Goemans 2006; Huth 1996; Huth, Croco, and Appel 2013; Kocs 1995; Laitin 2004; Larson and Lewis 2018; Morelli and Rohner 2015; Paine 2019; Posen 1993; Siroky and Dzutsev 2015; Walter 2009; Weidmann 2009; Zacher 2001). However, the distinctively ideational value of homeland territory is rarely incorporated as a variable. Sometimes this is the case because homelands are conceptualized as a constant that cannot explain variation in the existence, onset, or severity of conflict (e.g., Walter 2009). Other times, the ideational value of homelands is minimized as cheap talk by leaders seeking to mobilize support. From this perspective, because leaders "can easily embed symbolic value onto claimed territory," whether the territory has symbolic value is irrelevant for testing alternative explanations of enduring conflict (Wiegand 2011,39). Even some work on "what makes territory important" excluded nationalist attachment to homelands as a potential answer to this question (Dzurek 2005).

The elision of the role homelands play even characterizes much scholarship on the fundamentally territorial projects of irredentism, secession, and partition. Studies of irredentism, for example, conventionally assume that the desire to expand a state's borders stems from the presence of coethnics on adjacent territory rather than from a desire for the land itself (Ambrosio 2001; Chazan 1991; Goemans and Schultz 2017; Kornprobst 2008; Saideman and Ayers 2008; Siroky and Hale, 2017; Weiner 1971; for exceptions see Ben-Israel 1991; Shelef 2020a).

Many studies of secession take the boundaries of the area sought by the secessionist movement for granted, as the background against which secessionist conflict takes place. This is especially the case where explanations of secessionism focus on the structural inequalities and on the economic and political grievances that underpin many secessionist projects (Bartkus 1999; Griffiths 2020; Gurr and Moore 1997; Horowitz 2001). Yet, as other scholarship has shown, the geographical scope of the area stateless nationalist movements and their populations seek can change in ways that affect both the substance of secessionist conflict and the range of potential resolutions available for those conflicts (Mylonas and Shelef 2014; O'Leary, Lustick, and Callaghy 2001; Shelef and Zeira 2017).

Likewise, many proponents of partition as a strategy of conflict resolution, while acknowledging the importance of a territory's demographic and strategic characteristics, also tend to downplay the relevance of nationalists' ideational attachment to their homeland. From this perspective, territory is fungible; any territory will do for the location of the national state as long as it has relatively defensible borders and is reasonably ethnically homogenous (Chapman and Roeder 2007; Downes 2001; Johnson 2008; Kaufmann 1996, 1998; Mearsheimer 2000; Saideman and Ayers 2000; Tir 2005; Van Evera 1994). Yet, as critics of partition have noted, territorial partitions may carry within them the seeds of future conflict if only because the rump state may seek the reunification of its, now partitioned, homeland (O'Leary 2007).

The common omission of the ideational value of homelands is problematic because, as we elaborate below, this value likely affects the ways in which nationalists calculate the costs and benefits of territorial conflict and compromise. Scholars have long argued that homelands have a quasi-religious power, that they are nationalist "sacred ground" (Burghardt 1973; Hassner 2010; Murphy 2002; Smith 2000). Consistent with this expectation, experimental studies demonstrate that the sanctity of homelands structures the preferences of nationalists in very much the same way that religious values structure the preferences of believers (Ginges et al. 2007; Ginges and Atran 2009). The sacred value of homelands matters because, as a robust psychological literature makes clear, sacred values shape decision-making even though their value is measured along a nonmaterialist metric (Fiske and Tetlock 1997; Ginges and Atran 2009; McGraw and Tetlock 2005; McGraw, Tetlock, and Kristel 2003; Tetlock 2003; Tetlock et al. 2000). This could help explain why states hold on to disputed lands or engage in irredentist projects for territory with little material value and at tremendous cost (Hensel and Mitchell, 2005; Saideman and Ayers 2008; Tir 2010; for a contrasting view see Sosis 2011). In other words, although material and demographic considerations clearly matter, there are good reasons to believe that the value of homelands is not reducible to these considerations. 


\section{How Do Homelands Matter?}

Homelands can shape outcomes like violence, separatism, and irredentism through a number of mechanisms, including shaping rational cost-benefit calculations, molding the biases that structure cognitive processes, or triggering emotional reactions. At the group level, all of these mechanisms are observationally equivalent because they all make it easier to mobilize for collective action. As we note below, analysis at the individual level may be especially well suited to disentangling the operation of these mechanisms.

From a standard rationalist perspective, homelands can facilitate coordination by providing a clear criterion for defining group membership. The clear distinction between in-group members and outsiders makes norm compliance (such as the defense of the homeland) easier to enforce because it facilitates the identification of who should be adhering to the norm and therefore makes it easier to sanction them if they violate it. In this way, homelands enable the effective operation of a coordination mechanism that fosters successful collective action. Also assuming a rational costbenefit calculation but relying on social identity theory (Hogg and Abrams 1988), homelands could also induce individuals to successful collective action because the constitutive character of the national homeland for the nation means that violations of the homeland would contradict individuals' own understanding of who they are (Goemans, Weintraub, and Zhao 2021). From this perspective, the cost of losing homeland territory includes not just the land's material value but also the cognitive dissonance of a threat to one's own identity.

Homelands can also shape international relations outcomes by structuring the systematic biases that shape cognitive processes. For instance, the identification of a particular territory as part of the homeland may set the reference point against which changes in territorial arrangements are evaluated. As work in prospect theory has found, since reference points may be aspirational or imagined (Jervis 2004; Kahneman and Tversky 1982; McDermott 1998; Mercer, 2005; Tversky and Kahneman 1981), the loss of homeland territory, even if it occurred long ago, may place individuals in the domain of losses in ways that the loss of non-homeland territory (which may be excluded from the reference point) does not. As a result, the loss of homeland territory would elicit more riskacceptant behavior to regain it and lower the likelihood that compromises that involve coming to terms with its loss would be accepted (Kadercan 2017; Levy 1996).

The sacred value of the homeland may also contribute to conflict more directly. As a sacred value for nationalists, compromise over homelands may be seen as taboo and protected from the material tradeoffs (Tetlock 2003) that often constitute key elements of conflict resolution strategies. Indeed, given their sacred value, the attempt to use material gains to compensate for the loss of homeland territory may even backfire, leading to greater intransigence (Ginges et al. 2007). Consistent with this possibility, recent fMRI research on how sacred values are processed found less activation in neural areas associated with cognitive control and utilitarian reasoning compared to the processing of nonsacred values (Hamid et al. 2019). As a whole, these findings suggest that choices involving sacred values are less dependent on material cost-benefit calculations than choices involving nonsacred values, and thus that individuals may be less sensitive to the costs of conflict when they are implicated.

Importantly, homelands, precisely because they set the reference point against which reality is evaluated, can also moderate conflict. The role of homelands in nationalism suggests that nationalist territorial ambitions, while perhaps expansive, are not infinite; rather they are limited to the area of the homeland. As a result, nationalists' claims that their territorial demands are limited are more credible than they might otherwise be, reducing the risk to other entities of conceding to these demands, and thus facilitating conflict resolution (Schultz and Goemans 2019).

Homelands may also shape outcomes of interest through emotional processes, not just cognitive ones. For instance, the loss of homeland territory, because of its great value and constitutive importance to nations, may be perceived as especially humiliating (Barnhart 2017; Wang 2012). The emotion of humiliation, in turn, may make conflict more likely as it increases individuals' preferences for conflict by suppressing their sensitivity to its costs (Masterson 2021). Additional 
work exploring the full range of effects of the humiliation induced by the loss of homeland territory is needed, especially as other work has found that the experience of humiliation, while reducing support for compromise, may not contribute to political violence (Ginges and Atran 2008).

Consistent with these individual-level mechanisms, research has flagged the ability of a territory's symbolic value to increase the salience of territories in conflict and to shape the politics of such cases by mobilizing domestic support, enabling state leaders to fight off domestic challengers, and constraining their ability to make territorial concessions (Goddard 2010; Huth 2000; Kadercan 2017; Mansfield and Snyder 2007; Miller 2007; Snyder 2000; Toft 2003; Vasquez and Valeriano 2008). Hensel and Mitchell (2005), for example, find that while the material values of land shape low-level militarized disputes, territory's ideological salience has a stronger impact on fatal militarized disputes or full-scale interstate wars. Kelle (2017) finds that ethnic groups are more likely to seek independence over lands characterized by ideational values than those without. Shelef (2016; 2020a) demonstrates that lost land discursively designated as part of the homeland is associated with more international conflict over that territory, and that removing this designation is associated with a subsequent reduction in conflict.

\section{How and Where to Measure Homelands?}

Scholarship incorporating the value of homelands has used a range of approaches that vary both in terms of the particular way the homeland status of a territory is measured and the level of analysis at which this measurement is conducted.

Most large- $\mathrm{N}$ studies of international conflict that integrate homelands tend to rely on three proxies (either alone or in combination) to distinguish between homeland and non-homeland territory: territory populated by coethnics (e.g., Huth 1996; Toft 2003), state borders (e.g., Schultz 2017), or a group's history of prior autonomy in a territory (e.g., Walter 2009; Miller 2007). In pioneering work, the Issue Correlates of War project (ICOW) (Hensel 2001; Hensel and Mitchell 2015) combined these elements into a single index of a territory's "intangible" value. In a more recent index, Kelle (2017) usefully incorporates the presence of cultural heritage and sacred sites into a measure of the territory's ideational value.

Each of these measures certainly captures an important facet of the connection between a nation and its homeland. Yet, relying on these proxies comes at the cost of maintaining the gap between conventional theoretical understandings of nationalism and the data used to evaluate the role of homelands. This gap is reflected in three main areas.

First, the reliance on the past location of coethnics and a history of prior autonomy in a territory to identify homelands renders homelands necessarily static. Once prior autonomy or the past presence of coethnics is established in a space, measures of the homeland status of territory that rely on those proxies would forever count that land as part of the homeland. While consistent with a notion of homelands as indivisible (Fearon 1995), this static conception of homelands is at odds with the predominant understanding of nationalism in general, and territorial indivisibility in particular, as socially constructed and, as a result, subject to variation and reinterpretation.

Indeed, both theories of nationalism and historical experience suggest that homelands can vary over time. Few German nationalists still lay claim to the territory east of the Oder-Neisse Rivers that was once such a central part of their homeland. Indian nationalists rarely include Pakistan or Bangladesh in the scope of the Indian homeland. Israeli nationalists almost uniformly exclude the claim to the East Bank of the Jordan River. Even Italian nationalism, whose desire for its terra irredenta in the Istrian peninsula led to the coining of the term "irredentism," no longer includes those parts of Croatia and Slovenia within the Italian homeland (Shelef 2010, 2020a, 2020b). To be sure, not all homelands change. Yet static measures of the homeland status of territory limit our ability to investigate when and under what conditions such changes might be more or less likely.

Second, these proxies impose a level of analysis (see below) that assumes a unitary and domestically undifferentiated view of the homeland within a population. Tying the homeland to 
a particular group (whose ancestors resided in a territory or who possessed a measure of autonomy in it) limits the scope of variation to that existing between groups and prevents analysis of variation within a particular group and its impact. Yet, given the commonplace expectation of internal variation and contestation over other aspects of nationalism and social identity (Abdelal et al. 2006), there is good reason to expect that actors within a single group can disagree about the extent of the homeland or the ideational value of particular tracts of land as well (Shelef 2010, 2020a).

There are at least two kinds of internal variation regarding the homeland that are especially relevant. The first, and most direct, is over exactly which parcels of land ought to be included in the homeland (Sosis 2011). The empirical existence of internal variation on this question has been identified in a wide range of cases, including in the Croatian, Ethiopian, Indian, Irish, Israeli, Macedonian, Palestinian, Pakistani, Polish, Romanian, and Russian contexts (Chatterji 1994; Goddard 2010; Kristof 1994; Mylonas and Shelef 2017; Saideman and Ayers 2008; Shelef 2010, 2020a). The existence of different map images of the homeland within a society may matter because it could reflect internal variation in the ideational value of particular parcels of land within a group, variation that raises the possibility of different calculations about how much should be sacrificed in their name.

There may also be internal variation in why groups consider particular parcels of land as part of the homeland. Nationalists deploy a range of logics with which to assert that land is part of their homeland, including historical, legal, religious, demographic, security, and economic rationales, often in combination. As Shelef (2020a) argues, these different logics of legitimation can have divergent territorial implications and domestic political consequences. For example, ethnically based justifications are relatively more difficult to sustain with regard to areas that do not contain significant numbers of coethnics (or that no longer do), while religious and historical justifications can be applied with less regard for changing realities. Logics of legitimation also limit what those deploying them can credibly do. For example, while the German Christian Democratic Union's emphasis on international law and self-determination helped legitimate the reunion of West Germany with the Saar and East Germany, it undermined their ability to claim the lands east of the Oder-Neisse line after Poland's transition to democracy (Shelef 2020a). As Goddard (2010) showed, different logics of legitimation also mobilize different constituencies, who may or may not share the homeland commitments of others in their society. The mobilizational consequences of alternative logics of legitimation can therefore shape who is part of the ruling coalition and leaders' flexibility on territorial issues.

Third, each of these proxies also risks introducing systematic biases into the resulting analyses and limits the kinds of questions that they can answer. For example, using the prior location of coethnics as the proxy for delimiting the homeland excludes the homelands of so-called civic nations (whose membership criteria are not based on shared ethnic membership). Moreover, the assumption that ethnicity and homelands automatically correspond makes it impossible to empirically investigate whether ethnicity and homeland territoriality can vary independently or have distinct impacts on outcomes of interest, including conflict. Likewise, using state borders as a proxy risks succumbing to a methodological nationalism in which states' claims to represent nations are taken at face value. It is also likely to miscategorize cases where state borders included land that was not part of their homeland (e.g., Israel's control of the Sinai between 1967 and 1982) or homeland territory that was excluded from state control (e.g., the Hungarian pining for the pre-Trianon borders).

Recent scholarship has attempted to respond to these concerns by developing ways of detecting the homeland status of territory that are more consistent with the dominant, constructivist understanding of nationalism. Shelef (2016, 2020a, 2020b), for example, identifies the homeland status of territory based on the domestic discourse about land newly located on the other side of international borders. This approach is based on the understanding that since homelands are a nationalist form of territoriality, their physical contours have to be clearly articulated and continually demarcated. As a result, nationalists exert tremendous energy to maintain, if sometimes banally, the territorial boundaries of the homeland (Agnew 2007; Billig 1995; Black 1998; Newman 
2001, 2004; Paasi 1996; Winichakul 1997). Such a discourse-based measure of the homeland status of territory delinks homeland status from other dimensions of nationalism (most prominently, ethnicity) and allows the homeland status of particular territories to vary over time without making any assumptions about the relationship between the geographic distribution of coethnics and the extent of homeland territory, the length of time beyond which prior autonomy is no longer relevant, or the necessary congruence of homelands and state borders.

The choice of measurement strategy is also linked to a decision about the appropriate level of analysis for conducting research on homelands. Most studies, especially large-N cross-national ones, continue to situate their analysis at the level of the unitary ethnic group or the state (Bartkus 1999; Goemans and Schultz 2017; Gurr and Moore; Hensel and Mitchell 2005, 2015; Horowitz 2001; Huth 1996; Saideman and Ayers, 2000; Schultz 2017; Shelef 2016; Shelef 2020b; Toft 2003). Doing so is certainly understandable because nearly all other available data on both outcomes (e.g., conflict) and demographic, social, and economic covariates are coded at this level.

This practical consideration, however, often comes at the expense of eliding the internal variation that both theory and empirical experience suggest exists around the globe. As a result, other approaches, usually deploying structured case comparisons rather than quantitative analysis, situate their analysis at the level of the political movement articulating the homeland claim (Goddard 2010; Shelef 2010, Shelef 2020a; Mylonas and Shelef 2014). These movement-level analyses are part of the growing trend in conflict studies more generally that disaggregates actors in conflict (Buhaug, Cederman, and Rød 2008; Cunningham 2014; Cunningham, Bakke, and Seymour 2012; Cunningham, Dahl, and Frugé, 2017; Staniland 2012). This level of analysis, since it captures any existing internal variation, is especially useful for examining processes, like outbidding and evolutionary dynamics, that require variation in order to operate.

Finally, a growing body of work, corresponding to the micro turn in political science more generally, has begun to explore the value and impact of homelands at the individual level. Like the focus on political movements, this level of analysis allows for fine-grained examinations of variation and change. It is, however, largely constrained to contemporary investigations and experimental approaches because time-series individual level data about the scope and relevance of territorial claims is, with few exceptions, rarely available (Mylonas and Shelef 2017). ${ }^{1}$

Broadly speaking, observational studies have validated the expectation that the ideational value of homeland territory shapes attitudes at an individual level. For example, reinforcing nationalist theories of territorial salience, Gibler, Hutchison, and Miller (2012) find that territorial conflict influences the self-identification of individuals with the nation. Likewise, Kim (2020) finds that individuals are more willing to fight for their countries when its territory is contested.

Consistent with the insight that there is likely to be domestic variation in the homeland status allocated to a particular territory, the micro turn in studies of territory and conflict finds that individual-level covariates can shape the salience of the ideational value of the homeland relative to other factors. Tanaka (2016), for example, finds that those less affected by economic considerations can afford to maintain a hawkish stance in territorial disputes, while those economically affected by the conflict are more likely to compromise. Manekin, Grossman, and Mitts (2019) show that, in the Israeli context, those on the political right are more attached to homeland territory, while those in the center and left of the political spectrum are more likely to prioritize other issues such as security and economic well-being.

At the same time, the ability of observational cross-sectional work, whether at the level of the individual, the movement, or the state, to fully identify the causal impact of homelands remains limited. While time-series data can leverage temporality for causal inference, it is still inherently limited in addressing concerns about both endogeneity and omitted variables. As a result, recent experimental work has sought to causally identify the role of homelands and to more firmly explicate the mechanisms through which any impact is exerted. In this vein, Manekin, Grossman, and Mitts (2019) and Zellman (2018), for example, seek to disentangle the ideational impact of homeland territory from its material or strategic value. As noted above, Ginges and Atran (2009) 
demonstrated that homelands function like sacred values more generally. A critical finding of this research is that offering material incentives to compromise over the homeland yields a backlash rather than encourages compromise, but that symbolic concessions can facilitate conflict resolution (Ginges et al. 2007; Sheikh, Ginges, and Atran 2013). Similarly consistent with the possibility that the ideational value of homelands tends to trump material concerns, Rich (2019) finds that support for unification remains strong among Korean survey participants, even when primed with its anticipated costs. Other work on territorial compromise from the perspective of prospect theory has investigated various ways of ameliorating the "state of loss" (Gayer et al. 2009) or the negative emotions involved with compromise over homeland territory (Halperin et al. 2013). Scholars are also currently exploring the purchase of rationalist mechanisms and those arising from prospect theory in linking homelands to a willingness to engage in conflict (Goemans, Weintraub, and Zhao 2021; Zhao, Goemans, and Weintraub 2020).

To date, the experimental explorations of the impact of homelands have yielded some contradictory results. For example, much of the work asserting a role for homelands assumes that it operates through a framing effect. In this vein, Fang and Li (2020), for example, find that individuals' hawkish stance on territorial disputes could be triggered by historical ownership frames. Zellman $(2018,2020)$, however, finds that frames emphasizing the material importance of disputed land are more impactful than those framing its symbolic value. More broadly, as we note in the conclusion, orienting research on homelands to the causal mechanisms may require a rethinking of how to measure the impact of homelands in ways that leverage differences between territories, populations, and times to better understand how and why homelands matter.

\section{Conclusion}

The integration of nationalism and homelands into studies of conflict has moved a great deal beyond the observation that their indivisibility could be a reason for war (Fearon 1995). Yet, much remains to be done to more fully integrate homeland territoriality as a variable rather than as a fixed attribute of a territory or a group. Continuing to develop data about the variation in the homeland status of a territory can help answer critical questions about the conditions under which lands become consecrated as part of the homeland, the particular mechanisms through which this occurs, how homeland territory loses its status, and the conditions under which these changes occur.

Pursuing these questions will require the generation and collection of additional data, especially at the individual and substate (movement) levels. The time and area expertise required to generate data on the variation and transformation over time of homelands at these levels of analysis may constrain such investigations to particular cases. As a result, complementary projects aimed at systematically aggregating the findings from case study research are also needed. Advances in the ability of machine learning to conduct text and image analysis may be especially helpful in this regard. Overall, the merging of insights gained from the case-based scholarship pitched at the movement level with systematic cross-national investigations is one of the frontiers in this area of scholarship.

Additional work is also needed to capture important variation in the strength of national attachments at both the territorial and individual levels. At the territorial level, nearly all existing scholarship codes the homeland status of territory in binary terms, as being part of the homeland or not. Yet, it is possible, just like there are degrees of holiness, that homelands are better understood in interval or even continuous terms, with core areas having more homeland status than peripheral ones. Likewise, it is reasonable to expect individual-level variation in the attribution of homeland status to territory to shape the microfoundations of conflict. This, however, presents a challenge for observational research designs since an individual's ideational attachment to their homeland may be both exogenous to outside factors like conflict, state repression, and other political opportunities, and likely to be shaped by these factors. Experimental approaches are especially well suited to disentangling these aspects. 
The experimental turn in political science is also well positioned to enrich our understanding of the emotional, psychological, and cognitive mechanisms through which individual attachment to the homeland is constructed and modified, and therefore the mechanisms that mediate the role homelands play in politics. Particular attention could be paid, for example, to distinguishing the relative (and often cross-cutting) impact of a territory's material value from its role as part of the homeland. Similarly, despite Shelef s (2016, 2020a) findings, it is possible that any territorial loss, including the loss of non-homeland territory, may be sufficient to place individuals in the domain of losses and thereby render them more conflict acceptant (Zhao, Goemans, and Weintraub 2020).

More broadly, the specification of causal mechanisms through which homelands shape outcomes of interest may require a refocusing of how the concept is measured. In particular, attention should be paid to disentangling the impact of homelands from both that of national identity more broadly and from state borders. Homelands are also, as we have suggested above, a bundled treatment that implicates a variety of cognitive and emotional mechanisms. The cutting edge of scholarship on this topic will thus need to focus on unbundling homelands to identify what it is about them that matters in different contexts and disentangling the mechanisms through which they shape international politics and conflict.

Disclosures. None.

\section{Note}

1 Some of the exceptions include historical survey work in Israel and Palestine, Germany, Taiwan, and South Korea. See, for example, data collected by the "Peace Index" (http://www.peaceindex. org/DefaultEng.aspx) and Israeli Democracy Institute in Israel (https://en.idi.org.il/tags-en/ 1465), the quarterly surveys of the Palestinian population by the Palestinian Center for Policy and Survey Research (http://pcpsr.org/en), surveys about West German attitudes toward unification collected by Schweigler (1975) and Noelle-Neumann (1991), survey data collected by the project of Korean General Social Survey (KGSS) (https://www.icpsr.umich.edu/web/ICPSR/ series/288) on attitudes toward Korean unification, and the Election Study Center of National Chengchi University on the stances of Taiwanese (https://esc.nccu.edu.tw/PageDoc/Detail?fid= 7801\&id=6963) toward unification/independence.

\section{References}

Abdelal, Rawi, Yoshiko M. Herrera, Alastair Iain Johnston, and Rose McDermott. 2006. "Identity as a Variable." Perspectives on Politics 4 (4): 695-711.

Abramson, Scott F., and David B. Carter. 2016. "The Historical Origins of Territorial Disputes." American Political Science Review 110 (4): 675-698.

Agnew, John. 1994. "The Territorial Trap: The Geographical Assumptions of International Relations Theory." Review of International Political Economy 1 (1): 53-80.

Agnew, John. 2007. "No Borders, No Nations: Making Greece in Macedonia." Annals of the Association of American Geographers 97 (2): 398-422.

Ambrosio, Thomas. 2001. Irredentism: Ethnic Conflict and International Politics. Illustrated edition. Westport, CT: Praeger. Anderson, Benedict. 1991. Imagined Communities: Reflections on the Origin and Spread of Nationalism. London: Verso.

Barnhart, Joslyn. 2017. “Humiliation and Third-Party Aggression.” World Politics 69 (3): 532-568.

Bartkus, Viva Ona. 1999. The Dynamic of Secession. Cambridge: Cambridge University Press.

Ben-Israel, Hedva. 1991. “Irredentism: Nationalism Reexamined." In Irredentism and International Politics, edited by Naomi Chazan, 9-22. Boulder, CO: Lynne Rienner Publishers.

Billig, Michael. 1995. Banal Nationalism. Thousand Oaks, CA: SAGE.

Black, Jeremy. 1998. Maps and Politics. Chicago, IL: University of Chicago Press.

Buhaug, Halvard, Lars-Erik Cederman, and Jan Ketil Rød. 2008. "Disaggregating Ethno-Nationalist Civil Wars: A Dyadic Test of Exclusion Theory.” International Organization 62 (3): 531-551.

Burghardt, Andrew F. 1973. “The Bases of Territorial Claims.” Geographical Review 63 (2): 225-245.

Carter, David B. 2010. “The Strategy of Territorial Conflict.” American Journal of Political Science 54:969-987. 
Carter, David B., and Hein E. Goemans. 2011. "The Making of the Territorial Order: New Borders and the Emergence of Interstate Conflict.” International Organization 65 (2): 275-309.

Cederman, Lars-Erik. 2013. "Nationalism and Ethnicity in International Relations." In Handbook of International Relations, edited by Walter Carlsnaes, Thomas Risse, and Beth A. Simmons, 530-554. Thousand Oaks, CA: Sage.

Chapman, Thomas, and Philip G. Roeder. 2007. "Partition as a Solution to Wars of Nationalism: The Importance of Institutions.” The American Political Science Review 101 (4): 677-691.

Chatterji, Joya. 1994. Bengal Divided: Hindu Communalism and Partition, 1932-1947. Cambridge: Cambridge University Press. Chazan, Naomi, ed. 1991. Irredentism and International Politics. Boulder, CO:Lynne Rienner Pub.

Conzen, Michael P. 1993. "Culture Regions, Homelands, and Ethnic Archipelagos in the United States: Methodological Considerations.” Journal of Cultural Geography 13 (2): 13-29.

Cunningham, Kathleen Gallagher. 2014. Inside the Politics of Self-Determination. Illustrated edition. Oxford: Oxford University Press.

Cunningham, Kathleen Gallagher, Kristin M. Bakke, and Lee J. M. Seymour. 2012. "Shirts Today, Skins Tomorrow: Dual Contests and the Effects of Fragmentation in Self-Determination Disputes." Journal of Conflict Resolution 56 (1): 67-93.

Cunningham, Kathleen Gallagher, Marianne Dahl, and Anne Frugé. 2017. "Strategies of Resistance: Diversification and Diffusion." American Journal of Political Science 61 (3): 591-605.

Downes, Alexander B. 2001. “The Holy Land Divided: Defending Partition as a Solution to Ethnic Wars.” Security Studies 10 (4): 58-116.

Dzurek, Daniel J. 2005. “What Makes Territory Important: Tangible and Intangible Dimensions.” GeoJournal 64 (4): $263-274$.

Fang, Songying, and Xiaojun Li. 2020. "Historical Ownership and Territorial Disputes.” Journal of Politics 82 (1): $345-360$.

Fearon, James D. 1995. "Rationalist Explanations for War.” International Organization 49 (3): 379-414.

Fearon, James D., and David D. Laitin. 2003. "Ethnicity, Insurgency, and Civil War." The American Political Science Review 97 (1): 75-90.

Fiske, Alan Page, and Philip E. Tetlock. 1997. "Taboo Trade-Offs: Reactions to Transactions that Transgress the Spheres of Justice.” Political Psychology 18 (2): 255-297.

Gayer, Corinna Carmen, Shiri Landman, Eran Halperin, and Daniel Bar-Tal. 2009. "Overcoming Psychological Barriers to Peaceful Conflict Resolution: The Role of Arguments about Losses.” Journal of Conflict Resolution 53 (6): 951-975.

Gellner, Ernest. 1983. Nations and Nationalism. Ithaca, NY: Cornell University Press.

Gibler, Douglas M. 2012. The Territorial Peace: Borders, State Development, and International Conflict. Cambridge: Cambridge University Press.

Gibler, Douglas M., Marc L. Hutchison, and Steven V. Miller. 2012. "Individual Identity Attachments and International Conflict: The Importance of Territorial Threat." Comparative Political Studies 45 (12): 1655-1683.

Ginges, Jeremy, and Scott Atran. 2008. "Humiliation and the Inertia Effect: Implications for Understanding Violence and Compromise in Intractable Intergroup Conflicts." Journal of Cognition and Culture 8 (3-4): 281-294.

Ginges, Jeremy, and Scott Atran. 2009. "Noninstrumental Reasoning over Sacred Values: An Indonesian Case Study." Psychology of Learning and Motivation 50 (January): 193-206.

Ginges, Jeremy, Scott Atran, Douglas Medin, and Khalil Shikaki. 2007. "Sacred Bounds on Rational Resolution of Violent Political Conflict.” Proceedings of the National Academy of Sciences 104 (18): 7357-7360.

Goddard, Stacie E. 2010. Indivisible Territory and the Politics of Legitimacy: Jerusalem and Northern Ireland. Cambridge: Cambridge University Press.

Goemans, Hein. 2006. “Bounded Communities: Territoriality, Territorial Attachment, and Conflict.” In Territoriality and Conflict in an Era of Globalization, edited by Barbara F. Walter and Miles Kahler, 25-61. Cambridge: Cambridge University Press.

Goemans, Hein E., and Kenneth A. Schultz. 2017. “The Politics of Territorial Claims: A Geospatial Approach Applied to Africa." International Organization 71 (1): 31-64.

Goemans, Hein E., Michael Weintraub, and Andi Zhao. 2021. "Maps to Die For? Pre-Analysis Plan - Revised for Chile Survey.” Pre-Analysis plan. https://osf.io/h6vqk/. (Accessed June 10, 2021.)

Gottmann, Jean. 1973. The Significance of Territory. Charlottesville: University Press of Virginia.

Griffiths, Ryan D. 2020. “Secessionist Strategy and Tactical Variation in the Pursuit of Independence.” Journal of Global Security Studies 6 (1).

Gurr, Ted Robert, and Will H. Moore. 1997. "Ethnopolitical Rebellion: A Cross-Sectional Analysis of the 1980s with Risk Assessments for the 1990s.” American Journal of Political Science 41 (4): 1079-1103.

Hall, Rodney Bruce. 1999. National Collective Identity: Social Constructs and International Systems. New York, NY: Columbia University Press.

Halperin, Eran, Roni Porat, Maya Tamir, and James J. Gross. 2013. "Can Emotion Regulation Change Political Attitudes in Intractable Conflicts? From the Laboratory to the Field.” Psychological Science 24 (1): 106-111.

Hamid, Nafees, Clara Pretus, Scott Atran, Molly J. Crockett, Jeremy Ginges, Hammad Sheikh, Adolf Tobeña, et al. 2019. "Neuroimaging 'Will to Fight' for Sacred Values: An Empirical Case Study with Supporters of an Al Qaeda Associate." Royal Society Open Science 6 (6). 
Hassner, Ron E. 2010. War on Sacred Grounds. Ithaca, NY: Cornell University Press.

Hechter, Michael. 2000. Containing Nationalism. Oxford: Oxford University Press.

Hensel, Paul R. 2001. "Contentious Issues and World Politics: The Management of Territorial Claims in the Americas, 18161992.” International Studies Quarterly 45 (1): 81-109.

Hensel, Paul R., and Sara McLaughlin Mitchell. 2005. “Issue Indivisibility and Territorial Claims.” GeoJournal 64 (4): $275-285$.

Hensel, Paul R, and Sara McLaughlin Mitchell. 2015. "Lessons from the Issue Correlates of War (ICOW) Project." Journal of Peace Research 52 (1): 116-119.

Herb, Guntram H. 2004. "Double Vision: Territorial Strategies in the Construction of National Identities in Germany, 19491979." Annals of the Association of American Geographers 94 (1): 140-164.

Hogg, Michael A. and Dominic Abrams. 1988. Social Identifications: A Social Psychology of Intergroup Relations and Group Processes. London: Taylor and Francis.

Horowitz, Donald L. 2001. Ethnic Groups in Conflict. Updated edition with a new preface. Berkeley: University of California Press.

Huth, Paul K. 1996. Standing Your Ground: Territorial Disputes and International Conflict. Ann Arbor: University of Michigan Press.

Huth, Paul K. 2000. “Territory: Why Are Territorial Disputes between States a Central Cause of International Conflict.” In What Do We Know about War, edited by John A Vasquez, 85-110. Lanham, MD: Rowman \& Littlefield Publishers.

Huth, Paul K., Sarah E. Croco, and Benjamin J. Appel. 2013. "Bringing Law to the Table: Legal Claims, Focal Points, and the Settlement of Territorial Disputes since 1945." American Journal of Political Science 57:90-103.

Jervis, Robert. 2004. “The Implications of Prospect Theory for Human Nature and Values.” Political Psychology 25 (2): $163-176$.

Johnson, Carter. 2008. “Partitioning to Peace: Sovereignty, Demography, and Ethnic Civil Wars.” International Security 32 (4): $140-170$.

Kadercan, Burak. 2017. "Nationalism and War for Territory: From 'Divisible' Territories to Inviolable Homelands." Cambridge Review of International Affairs 30 (4): 368-393.

Kahneman, Daniel, and Amos Tversky. 1982. “The Psychology of Preferences.” Scientific American 246 (1): 160-173.

Kaufmann, Chaim D. 1996. "Possible and Impossible Solutions to Ethnic Civil Wars." International Security 20 (4): $136-175$.

Kaufmann, Chaim D. 1998. "When All Else Fails: Ethnic Population Transfers and Partitions in the Twentieth Century." International Security 23 (2): 120-156.

Kelle, Friederike Luise. 2017. "To Claim or Not to Claim? How Territorial Value Shapes Demands for Self-Determination." Comparative Political Studies 50 (7): 992-1020.

Kim, Nam Kyu. 2020. “Territorial Disputes and Individual Willingness to Fight.” Journal of Peace Research 57 (3): $406-421$.

Kocs, Stephen A. 1995. "Territorial Disputes and Interstate War, 1945-1987." The Journal of Politics 57 (1): 159-175.

Kohn, Hans. 1939. “The Nature of Nationalism.” The American Political Science Review 33 (6): 1001-1021.

Kornprobst, Markus. 2008. Irredentism in European Politics: Argumentation, Compromise and Norms. Cambridge: Cambridge University Press.

Kristof, Ladis K. D. 1994. “The Image and the Vision of the Fatherland: The Case of Poland in Comparative Perspective." In Geography and National Identity, edited by David Hooson, 221-232. Oxford: Basil Blackwell.

Laitin, David D. 2004. "Ethnic Unmixing and Civil War." Security Studies 13 (4): 350-365.

Larson, Jennifer M., and Janet I. Lewis. 2018. "Rumors, Kinship Networks, and Rebel Group Formation.” International Organization 72 (4): 871-903.

Levy, Jack S. 1996. "Loss Aversion, Framing, and Bargaining: The Implications of Prospect Theory for International Conflict.” International Political Science Review 17 (2): 179-195.

Lustick, Ian. 1993. Unsettled States, Disputed Lands: Britain and Ireland, France and Algeria, Israel and the West Bank-Gaza. Ithaca, NY: Cornell University Press.

Manekin, Devorah, Guy Grossman, and Tamar Mitts. 2019. “Contested Ground: Disentangling Material and Symbolic Attachment to Disputed Territory." Political Science Research and Methods 7 (4): 679-697.

Mansfield, Edward D., and Jack Snyder. 2007. Electing to Fight: Why Emerging Democracies Go to War. Cambridge, MA: MIT Press.

Masterson, Michael. 2021. “Humiliation and International Conflict Preferences." Journal of Politics. Published online ahead of print March 26, 2021. doi: 10.1086/715591.

McDermott, Rose. 1998. Risk-Taking in International Politics: Prospect Theory in American Foreign Policy. Ann Arbor: University of Michigan Press.

McGraw, A. Peter, and Philip E. Tetlock. 2005. “Taboo Trade-Offs, Relational Framing, and the Acceptability of Exchanges.” Journal of Consumer Psychology 15 (1): 2-15.

McGraw, A. Peter, Philip E. Tetlock, and Orie V. Kristel. 2003. “The Limits of Fungibility: Relational Schemata and the Value of Things." Journal of Consumer Research 30 (2): 219-229.

Mearsheimer, John J. 2000. "The Case for Partitioning Kosovo.” In NATO’s Empty Victory: A Postmortem on the Balkan War, edited by Carpenter T. G. Washington, DC: CATO Institute.

Mercer, Jonathan. 2005. "Prospect Theory and Political Science." Annual Review of Political Science 8 (1): 1-21. 
Miller, Benjamin. 2007. States, Nations, and the Great Powers: The Sources of Regional War and Peace. Cambridge: Cambridge University Press.

Morelli, Massimo, and Dominic Rohner. 2015. "Resource Concentration and Civil Wars." Journal of Development Economics 117 (November): 32-47.

Murphy, A. 2002. "National Claims to Territory in the Modern State System: Geographical Considerations." Geopolitics 7 (2): 193-214.

Mylonas, Harris, and Nadav G. Shelef. 2014. "Which Land Is Our Land? Domestic Politics and Change in the Territorial Claims of Stateless Nationalist Movements." Security Studies 23 (4): 754-786.

Mylonas, Harris, and Nadav G. Shelef. 2017. "Methodological Challenges in the Study of Stateless Nationalist Territorial Claims.” Territory, Politics, Governance 5 (2): 145-157.

Newman, David. 2001. "Boundaries, Borders, and Barriers: Changing Geographic Perspectives on Territorial Lines." In Identities, Borders, Orders: Rethinking International Relations Theory, edited by Mathias Albert, David Jacobson, and Yosef Lapid, 137-151. Minneapolis: University of Minnesota Press.

Newman, David. 2004. "From National to Post-National Territorial Identities in Israel-Palestine." In Israelis in Conflict: Hegemonies, Identities and Challenges, edited by Adriana Kemp, David Newman, Uri Ram, and Oren Yiftachel, 137-151. Portland: Sussex Academic Press.

Noelle-Neumann, Elisabeth. 1991. "The German Revolution: The Historic Experiment of the Division and Unification of Aa Nation as Reflected in Survey Research Findings.” International Journal of Public Opinion Research 3 (3): 238-259.

O'Leary, Brendan, Ian S. Lustick, and Thomas Callaghy, eds. 2001. Right-Sizing the State: The Politics of Moving Borders. Oxford: Oxford University Press.

O’Leary, Brendan. 2007. “Analysing Partition: Definition, Classification and Explanation.” Political Geography 26 (8): $886-908$.

Paasi, Anssi. 1996. Territories, Boundaries and Consciousness: The Changing Geographies of the Finnish-Russian Border. New York: Wiley.

Paine, Jack. 2019. "Economic Grievances and Civil War: An Application to the Resource Curse." International Studies Quarterly 63 (2): 244-258.

Penrose, Jan. 2002. "Nations, States and homelands: Territory and Territoriality in Nationalist Thought." Nations and Nationalisms 8 (3): 277-297.

Posen, Barry R. 1993. “The Security Dilemma and Ethnic Conflict.” Survival 35 (1): 27-47.

Rich, Timothy S. 2019. "South Korean Perceptions of Unification: Evidence from an Experimental Survey.” Georgetown Journal of International Affairs 20 (1): 142-149.

Sack, Robert D. 1986. Human Territoriality: Its Theory and History. Cambridge: Cambridge University Press.

Saideman, Stephen M., and R. William Ayres. 2000. "Determining the Causes of Irredentism: Logit Analyses of Minorities at Risk Data from the 1980s and 1990s.” Journal of Politics 62 (4): 1126-1144.

Saideman, Stephen M., and R. William Ayres. 2008. For Kin or Country: Xenophobia, Nationalism, and War. New York, NY: Columbia University Press.

Schultz, Kenneth A. 2017. "Mapping Interstate Territorial Conflict: A New Data Set and Applications." Journal of Conflict Resolution 61 (7): 1565-1590.

Schultz, Kenneth A., and Henk E. Goemans. 2019. “Aims, Claims, and the Bargaining Model of War.” International Theory 11 (3): 344-374.

Schweigler, Gebhard. 1975. National Consciousness in Divided Germany. Sage Publications.

Sheikh, Hammad, Jeremy Ginges, and Scott Atran. 2013. "Sacred Values in the Israeli-Palestinian Conflict: Resistance to Social Influence, Temporal Discounting, and Exit Strategies.” Annals of the New York Academy of Sciences 1299 (September): $11-24$.

Shelef, Nadav G. 2010. Evolving Nationalism: Homeland, Identity, and Religion in Israel, 1925-2005. Ithaca, NY: Cornell University Press.

Shelef, Nadav G. 2016. "Unequal Ground: Homelands and Conflict.” International Organization 70 (1): $33-63$.

Shelef, Nadav G. 2020a. Homelands: Shifting Borders and Territorial Disputes. Ithaca, NY: Cornell University Press.

Shelef, Nadav G. 2020b. “How Homelands Change.” Journal of Conflict Resolution 64 (2-3): 490-517.

Shelef, Nadav G., and Yael Zeira. 2017. "Recognition Matters! UN State Status and Attitudes toward Territorial Compromise." Journal of Conflict Resolution 61 (3): 537-563.

Siroky, David, and Valery Dzutsati. 2015. "The Empire Strikes Back: Ethnicity, Terrain, and Indiscriminate Violence in Counterinsurgencies.” Social Science Quarterly 96 (3): 807-829.

Siroky, David S., and Christopher W. Hale. 2017. "Inside Irredentism: A Global Empirical Analysis.” American Journal of Political Science 61 (1): 117-128.

Smith, Anthony D. 1987. The Ethnic Origins of Nations. Oxford: Basil Blackwell.

Smith, Anthony D. 2000. “The 'Sacred' Dimension of Nationalism.” Millennium: Journal of International Studies 29 (3): 791-814.

Snyder, Jack L. 2000. From Voting to Violence: Democratization and Nationalist Conflict. Illustrated edition. New York, NY:

W. W. Norton \& Company. 
Sosis, Richard. 2011. "Why Sacred Lands Are Not Indivisible: The Cognitive Foundations of Sacralising Land." Journal of Terrorism Research 2 (1): 17-44.

Staniland, Paul. 2012. "Between a Rock and a Hard Place: Insurgent Fratricide, Ethnic Defection, and the Rise of Pro-State Paramilitaries." Journal of Conflict Resolution 56 (1): 16-40.

Tanaka, Seiki. 2016. "The Microfoundations of Territorial Disputes: Evidence from a Survey Experiment in Japan." Conflict Management and Peace Science 33 (5): 516-538.

Taylor, Peter. 1994. “The State as Container: Territoriality in the Modern World-System.” Progress in Human Geography 18 (2): 151-162.

Tetlock, Philip E., Orie V. Kristel, S. Beth Elson, Melanie C. Green, and Jennifer S. Lerner. 2000. “The Psychology of the Unthinkable: Taboo Trade-Offs, Forbidden Base Rates, and Heretical Counterfactuals." Journal of Personality and Social Psychology 78 (5): 853-870.

Tetlock, Philip. 2003. “Thinking the Unthinkable: Sacred Values and Taboo Cognitions." Trends in Cognitive Sciences 7 (August): $320-324$.

Tir, Jaroslav. 2005. “Dividing Countries to Promote Peace: Prospects for Long-Term Success of Partitions.” Journal of Peace Research 42 (5): 545-562.

Tir, Jaroslav. 2010. "Territorial Diversion: Diversionary Theory of War and Territorial Conflict.” Journal of Politics 72 (2): 413-425.

Toft, Monica Duffy. 2003. The Geography of Ethnic Violence: Identity, Interests, and the Indivisibility of Territory. Princeton, NJ: Princeton University Press.

Tversky, Amos, and Daniel Kahneman. 1981. “The Framing of Decisions and the Psychology of Choice.” Science 211 (4481): 453-458.

Van Evera, Stephen. 1994. “Hypotheses on Nationalism and War.” International Security 18 (4): 5-39.

Vasquez, John A, and Brandon Valeriano. 2008. "Territory as a Source of Conflict and a Road to Peace." In The SAGE Handbook of Conflict Resolution, edited by Jacob Bercovitch, Victor Kremenyuk, and I. William Zartman, 191-209. Thousand Oaks, CA: SAGE.

Walter, Barbara F. 2009. Reputation and Civil War: Why Separatist Conflicts Are So Violent. Cambridge: Cambridge University Press.

Wang, Zheng. 2012. Never Forget National Humiliation: Historical Memory in Chinese Politics and Foreign Relations. New York, NY: Columbia University Press.

Weidmann, Nils B. 2009. “Geography as Motivation and Opportunity: Group Concentration and Ethnic Conflict.” The Journal of Conflict Resolution 53 (4): 526-543.

Weiner, Myron. 1971. "The Macedonian Syndrome: An Historical Model of International Relations and Political Development." World Politics 23 (4): 665-683.

Wiegand, Krista E. 2011. Enduring Territorial Disputes: Strategies of Bargaining, Coercive Diplomacy, and Settlement. Athens: University of Georgia Press.

Winichakul, Thongchai. 1997. Siam Mapped: A History of the Geo-Body of a Nation. Honolulu: University of Hawaii Press.

Zacher, Mark W. 2001. "The Territorial Integrity Norm: International Boundaries and the Use of Force." International Organization 55 (2): 215-250.

Zellman, Ariel. 2018. "Uneven Ground: Nationalist Frames and the Variable Salience of Homeland." Security Studies 27 (3): 485-510.

Zellman, Ariel. 2020. "Cheap Talk or Policy Lock? Nationalist Frames and Sympathetic Audience Costs in International Territorial Disputes.” Territory, Politics, Governance 8 (3): 336-355.

Zhao, Andi, Hein E. Goemans, and Michael Weintraub. 2020. "Historical Ownership Narratives and Loss Framing in Territorial Disputes." Paper presented at the annual conference of the American Political Science Association, San Francisco, September 10-13.

Cite this article: Shelef, N. G. and Koo, A. Z. -X. 2022. Homelands and Nationalism. Nationalities Papers 50: 417-429, doi:10.1017/nps.2021.38 